\title{
Human Resource Management and Organizational Performance-The Mediating Role of Organizational Commitment: Empirical Evidence from the Public Sector in a Non-Western Context
}

\author{
SUSAN ZEIDAN ${ }^{*} \cdot$ ASSAAD FARAH* \\ AND SHADI ABOUZEID*
}

\begin{abstract}
Research in the field of strategic human resource management has attracted a great deal of interest because of its likely impact on bottom line outcomes. Recent work in this area posits that organizational commitment can mediate the relationship between human resource management (HRM)practices and organizational performance. However, most of the studies conducted in this area were concentrated on samples gathered from private organizations, and mainly in western countries. In this paper, the impact of HRM on organizational performance is assessed. Furthermore, this research attempts to shed more light on the 'black box' between human resource practices and organizational performance by investigating the mediating function of organizational commitment in two public sector entities within the United Arab Emirates (UAE). The mediating factor was tested through regression of the data collected from a sample of 371 workers who are employed within the two aforementioned public sector entities. The main findings are in line with the outcomes of earlier HRM-performance studies conducted in western public and private sectors, where employers can expect improved organizational performance when their employees' perceptions of the HRM practices within the organization tend to foster an increase in their organizational commitment.
\end{abstract}

Keywords: Human Resource Management Practices,

Organizational Commitment, Organizational

Performance, Public Sector, Non-Western Context

Associate Professor of Management School of Business Administration, American University in Dubai; E-mail: szeidan@aud.edu

** Assistant Professor of Management School of Business Administration, American University in Dubai; E-mail: afarah@aud.edu

*** Associate Professor of Management School of Business Administration, American University in Dubai; E-mail: sabouzeid@aud.edu 


\section{INTRODUCTION}

$\mathrm{D}$

uring the past fifteen years, research in the strategic human resource management (SHRM) field has flourished substantially (Boselie et al. 2005). Stemming from the resource based view theory (Barney 1991), conceptualizations in this area mainly posit that human resources can play a significant role in influencing a firm's bottom line outcome. Accordingly, the essence of SHRM theories is that human resource (HR) policies can lead to higher levels of organizational performance (Boselie et al. 2005; Purcell et al. 2003, 2009). This rationale is supported with a growing number of studies which have demonstrated a positive relationship between HRM and firm performance (Arthur 1994; Becker and Gerhard 1996; Becker and Huselid 1998; Delaney and Huselid 1996; Huselid 1995; MacDuffie 1995). Nevertheless, while these studies have provided evidence in favor of the latter argument, it is fair to say that "how and why this takes place" remains an intricate issue to be investigated. This ambiguity in the HR-performance relationship is denoted by the 'Black Box' problem (Purcell et al. 2003). Indeed, according to Macky and Boxall (2007), scholars need to theoretically demonstrate the process through which HRM is linked to performance. In fact, more research is needed on the variables linking the input (HRM policies) to the output (performance indicators). They also argue that the role employee work attitudes play in mediating the relationship between high commitment management HRM practices and desired organizational outcomes remains unclear. They further argue that "these attitudes are potentially important proximal links or mediating variables within the black box of a firm's labour management" (540). In agreement, Guest $(2002,336)$ advocates placing workers "center-stage" in the analysis of HRM.

To this end, the present program of research seeks to address the gap highlighted above by attempting to peer into the black box.Specifically, this research tests links from HRM to performance via commitment (specifically affective commitment). Furthermore, previous research in this area has been focused on research in Western countries. To our knowledge, this research will be the first of its kind in the Gulf region and specifically in the United Arab Emirates.

\section{LITERATURE REVIEW}

\section{Uncovering the HR-performance Black Box}

Authors investigating the black box posit that the first factor that studies need to account for in unlocking the HR-performance link is the implementation of HR policies rather than the mere presence of these policies (Purcell et al. 
2003). In other words, it is essential that researchers refrain from counting the HR policies that exist in an organization and focus instead, on the actual HR practices. Secondly, in their attempt to uncover the linkages between HRM and performance, authors stress the importance of studying the employees as the central actors to whom these practices are being directed (Appelbaum et al. 2000). In effect, as HR practices primarily deal with the management of the workforce, employees can have a key function in the impact of HR practices on organizational performance (Chang 2005). Particularly, there is research evidence demonstrating that HR practices help shape employees' attitudes (Macky and Boxall 2007). In turn, studies have indicated that it is through their influence on workers' attitudes that HR practices can impact organizational performance (Purcell et al. 2009). In parallel, authors emphasize that it is not HR practices per se that affect employee attitudes but mainly the means through which employees view and experience these practices (Boselie et al. 2005; Bowen and Ostroff 2004; Kinnie et al. 2005). HRM is influential in forming the psychological contract between employer and employees, which affect perceptions, and can eventually lead to higher organizational performance (Ostroff and Bowen 2000). Therefore, in addition to accounting for HR practices (rather than policies), it seems essential that scholars examine workers' perceptions of HR practices. In sum, the current body of knowledge in the SHRM literature indicates that the linkages between HR policies and organizational performance could follow the pattern depicted in Figure 1 (adapted from Kinnie et al. 2005).

Figure 1. Understanding THE HR-Performance CONNECTION

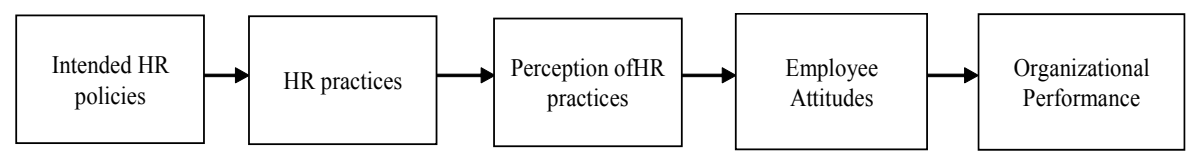

After presenting the linkages that could exist between HRM and a company's performance, it is important to indicate that many studies tend to measure HRM practices using a single respondent (generally the HR manager), which could lead to biased responses. This can be avoided if researchers collect data on HRM from several respondents within the organization. Eventually, as Kinnie et al. (2004) state, research needs to accumulate data from the very employees who are directly affected by the HRM policies.

As research has emphasized on the importance of employee attitudes within the HR-performance connections, a number of work attitude variables were investigated by SHRM scholars. Perhaps one of the constructs that were most often depicted as playing a central mediating function between HRM and performance is organizational commitment (Boselie et al. 2005; Chang 2005; Macky 
and Boxall 2007; Purcell et al. 2009, 2003). Since this paper is focusing on this mediating role for organizational commitment, and more specifically on the affective commitment dimension of it, the subsequent section defines and elaborates on this attitudinal variable.

\section{Organizational Commitment}

Employee commitment has been subject to extensive studies in the area of organizational research (Buitendach and De Witte 2005). There are three distinct dimensions of organizational commitment: affective, continuance, and normative commitment (Allen and Meyer 1990). According to Mowday et al. (1982), affective commitment is defined as an employee's identification with and involvement in a particular organization. Affectively committed employees possess strong psychological bonds with their firms, work in line with their company's values and exert additional effort to achieve organizational goals (Bagraim 2003; Mowday et al. 1979; Porter et al. 1974). On the other hand, continuance commitment is defined as the commitment that is based on the costs that the individual relates with leaving his or her company, whereas normative commitment delineates the feeling of being obliged to stay in the organization (Allen and Meyer 1990). As Allen and Meyer (1996) conceptualize, affective commitment is the most important, reliable and recognized of the aforesaid commitment dimensions. In fact, research demonstrates stronger associations between affective commitment, discretionary behavior and some measures of performance, than relations between these same variables and other types of commitment (Mayer and Schoorman 1992). According to Meyer and Herscovitch (2001), a possible explanation for why affective commitment correlates with a wider range of outcomes is that when commitment is accompanied by a mind-set of desire (such as the case with affective commitment), the behavioral consequences of commitment are perceived by the individual to be broader than when commitment is accompanied by a mind-set of provided cost or obligation. The authors argue that an individual with high affective commitment towards an organization is more likely to consider the best interests of that organization than someone with high continuance or normative commitment. They further recommend that wherever possible, it is desirable to foster affective commitment. Therefore, in this study, the term "organizational commitment" refers to the affective type of this construct.

Organizational commitment is related to absenteeism and turnover, and is influenced by individual and job characteristics, as well as work experience (Cascio 1998; Mowday et al. 1982). Additionally, research demonstrates that committed employees are less likely to quit their employing organization (Mayer and Schoorman 1992; Meyer and Allen 1997). Alternatively, committed incumbents tend to support their peers and subordinates and are more dedicated to organiza- 
tional policies and practices (Randall and O'Driscoll 1997). In effect, high levels of organizational commitment are imperative for the competitiveness of today's organizations (Corsun and Enz 1999). Downsizing and restructuring endeavors can have a destructive effect on the commitment levels of the remaining workforce (Hallier and Lyon 1996; Mone 1997). Nonetheless, organizational change necessitates highly committed personnel in order to implement new strategies and policies, and eventually maintain or attain high levels of work performance (Farrell 2003).

Subsequent to defining the organizational commitment construct it is important to shed light on two of the most supported and yet debated philosophies in the SHRM literature: the universal versus contingency approaches.

\section{The Universal and Contingency Approaches}

In studies on the HRM-performance link, theory often revolves around two main perspectives: universal and contingency. "'The universal' or 'best practices,' perspective implies a direct relationship between particular approaches to human resources and performance" (Youndt et al. 1996, 837). Advocates of the universalistic argument posit that the relationship between HRM practices and indicators of performance is universal across different organizational and geographical settings (such as countries) (Delery and Doty 1996). Alternatively, the contingency perspective is a more complex form of theorizing in human resource management. "Contingency theories posit that the relationship between the relevant independent variable and the dependent variable will be different for different levels of the critical contingency factor" (Delery and Doty 1996, 807). The most prominently used contingency factor is the firm's strategic direction or goals (Yound et al. 1996). Other examples of contingency factors could be the country, the sector, the size of the organization or the manufacturing practices (MacDuffie 1995; Youndt et al. 1996).

Many authors challenge the universalistic view and posit that this approach is subject to methodological and theoretical problems (Marchington and Grugullis 2000; Purcell 1999). The universal approach is too simplistic, and there is still no agreement over what type of practices to include in the universalistic HR list. Despite these arguments however, there is still a debate around theories on the universal and contingency approaches, and there remains no consensus over what perspective, if any, can maximize organizational performance. Indeed, there is no agreement over a universal set of HR practices (Purcell 1999), no identification of a uniformly efficient employment system (Delery and Doty 1996) and there is a need to achieve both fit and flexibility in contingency models (Boxall and Purcell 2003; Wright and Snell 1998). 


\section{The HR-Performance Link in the United Arab Emirates}

In their review of the HR-performance literature, Boselie et al. (2005) have exhibited that most studies conducted in the HR-performance literature were conducted in companies and organizations in the United States and the United Kingdom. However, there is a need for substantially more research into the aforementioned connection in other nations and geographical settings. In effect, if we acknowledge that employees are central actors to whom HR practices are being directed, there is a need to investigate whether workers from different nations (where factors such as culture, work ethics, perceptions and labor laws could vary) would react in the same manner to human resource practices. Hence while there is still no agreement on which approach (i.e. Contingent vs Universalistic) if any, is dominant it is necessary to conduct contingency studies in order to understand the possible influence of the aforementioned factors on the HR performance link.

In its attempt to contribute to the HR-performance literature, particularly towards the universal versus contingency perspectives to SHRM, the main aim of this paper is to assess the effect of a set of HR practices on performance in the United Arab Emirates. In effect, there is very little evidence in the body of knowledge on how HR practices can influence organizational performance in that part of the world. In effect while most companies including public sector entities follow a Westernized business model (mainly British and American) there could be factors within the business environment that could influence the HR-performance interconnection. Accordingly, the premises of this paper can be more closely related to the contingency perspective. However, strategy is not a contingency factor in this case. In fact, one of the major criticisms of strategy as a contingency is that HRM would ignore employees' interests (Boxall and Purcell 2003). This interest could be achieved by aligning HRM practices to the needs of specific contexts (Boxall and Purcell 2003); in this case the context of the UAE.

\section{THEORETICAL MODEL}

While many associations have been substantially studied in the HR-performance link, there is still a debate over what practices to include in HRM lists. Even though practices like training and development, rewards and selective hiring are present in the majority of $\mathrm{HR}$ lists, some more innovative practices such as participative decision-making and information sharing maybe less incorporated into these. Actually, in their attempt to develop HR practices' lists, researchers constructed different bundles based on the impact of those on diverse indicators, 
such as economic, financial, employee commitment, or skill development. For instance, researchers distinguish between "control" and "high commitment" human resource practices. Control policies are designed to decrease labor costs and increase work effectiveness by imposing strict job regulations, and relating rewards to individual or departmental performance (Arthur 1994). "High commitment" human resource practices aim to increase work effectiveness and company performance through employees' attitudes and behaviors, and are proven to amplify organizational performance more than control HRM systems (Arthur 1994). Irrespective of their classification (control or commitment), lists of HR practices are subject to many theoretical and methodological criticisms. For instance, Pfeffer (1999) claims that a universal set of "high commitment" practices is applicable to all national and industrial settings. This includes employment security, selective hiring, team working, performance related pay, training and development, egalitarianism and information sharing. Nonetheless, Marchington and Grugullis (2000) argue that Pfeffer's list is too simplistic and there is not enough evidence to suggest that this list could be universal. Moreover, Purcell (1999) denotes that even if there is an agreement over a particular list of practices, there is still a question mark on whether the organization needs all of the included policies. Additionally, other authors define another "high commitment" bundle, one that encompasses selective staffing, developmental appraisal, compensation, and, training and development (Ichniowski et al. 1997; MacDuffie 1995; Snell and Dean 1992; Youndt et al. 1996).

In relation to the aforementioned debate, more and more SHRM scholars are now demonstrating a set of $\mathrm{HR}$ practices that are predominantly and particularly associated with employees' attitudes-mainly, organizational commitment (Boselie et al. 2005; Macky and Boxall 2007; Purcell et al. 2009, 2003). The identification of these practicesis based on the framework that performance is related to Ability, Motivation and Opportunity (AMO). In other words, employees "perform better" if they possess the required skills and knowledge, if they are motivated to work well and if they are given the opportunity to apply their Knowledge Skills and Abilities in and off the job, or in any activity that can contribute to organizational success (Purcell et al. 2003). The list of such practices primarily encompasses the following: rewards and recognition, training and development, career opportunities, teamworking, participative decision-making, performance appraisal, information sharing, job security and selective hiring.

This paper adopts the AMO perspective and accordingly, investigates the impact of the aforementioned HR practices on organizational commitment and in turn, organizational performance within the context of the United Arab Emirates. The associations examined in this research are highlighted in the subsequent model (Figure 2). 
Figure 2. The HR Practices-Organizational Performance CONNECTION IN THE UAE

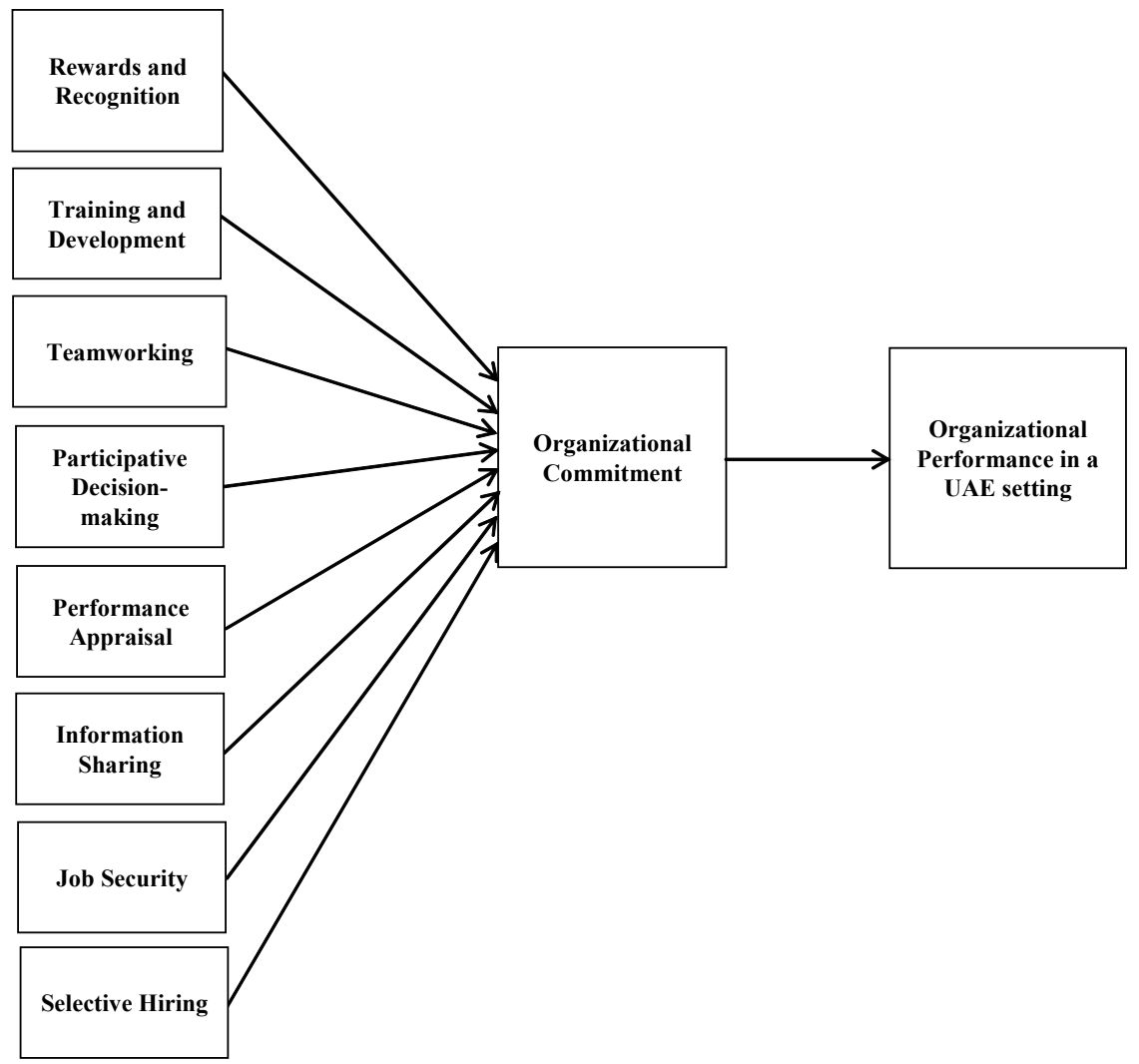

The following section describes the research design adopted in this paper in order to test the above model.

\section{Methodology}

\section{Sample and Data Collection Method}

A questionnaire survey was utilized to collect data for our study. The questionnaire started with a cover letter introducing the study and its aims, while clearly disclosing the identity of the researcher and promising confidentiality and anonymity for the respondents. The cover page ended on a courteous note, thanking the respondent for taking time to respond to the survey. In order to gather the data in an automated manner while ensuring confidentiality of data, NEPO software was utilized. NEPO is a tool that can be installed onto an entity's 
servers and allows for web posting of the surveys. This ensures that data is secure within the entity, and thus no breach of confidentiality would arise from using publicly available engines.

As obtaining support from management is helpful for gaining support from the respondents, confirming the purported use of the surveys, and increasing the probability of returning the questionnaires (Roth and BeVier 1998; Dillman 2000), approval to conduct the survey was obtained from the Director general of the organization. An official internal communication from the Director General's Office was communicated to all employees of two departments via an email which contained a link to the survey. It is worth noting that such types of surveys have been conducted with the same entities for the past five years. It was apparent that employees look forward to the yearly employee satisfaction surveys since they have witnessed the successful deployment of action plans that improves their conditions and work environment. Furthermore while this could be an issue in some entities within the region, the employees did not feel concerned about any lack of anonymity regarding the surveys, including this particular research.

The first department contained 199 full time employees, 174 of which responded to the survey, and the second department had 420 full time employees, 197 of which completed the survey. The sample is composed of $81 \%$ UAE nationals and $19 \%$ Expats with $70 \%$ of the workforce being less than 36 years of age, furthermore all participants possessed as a minimum a bachelor degree with the exception of 7 clerical worker who have a diploma. This email included information about the research, assured staff that their responses would be kept confidential, and that results would be grouped together so that no individual's responses could be identified. The researchers made sure that the chosen organization utilized a formalized HR system.

\section{Measurement}

The survey items were formulated from an extensive literature review. Multi-item scales were used for all the variables understudy to provide a comprehensive evaluation of these constructs. This is in accordance with Nunnally (1978) and Peter (1979) who argue that multi-scales are considered necessary for valid measurements of factorially complex constructs.

\section{(1) Human Resource Management Practices}

The study utilized $8 \mathrm{HRM}$ practices focused on building intellectual capital: 1) training and development, 2) participative decision making, 3) information sharing, 4) rewards and recognition, 5) teamwork, 6) job security, 7) selective hiring, and 8) performance appraisal. Respondents were asked to indicate the 
extent of their agreement with each item on a 5-point Likert-type scale, with 1 being "Strongly Agree," and 5 being "Strongly Disagree." The eight HRM practices listed above were measured as follows:

Training and Development: Training and development was measured using a 5-item scale from Gaertner and Nollen (1989). This measure evaluates the extent to which employees feel that they receive adequate training and development opportunities within the organization. This scale was originally used in a sample of employees from a Fortune 100 manufacturing firm, where Gaertner and Nollen (1989) reported an alpha coefficient of 0.805 . This scale was used with only a minor change in which the word "company" was replaced by "organization." A sample item is, "Training is regarded as a way to improve performance."

Participative Decision Making: Participative decision-making was measured using Vandenberg et al.'s (1999) 7-item "power" scale. This scale was initially used on a sample of 3,570 employees from 49 life insurance companies located in the United States and Canada. Within each company, 20\% of employees were randomly sampled using a stratified scheme so that all organizational levels were represented. Vandenberg et al. (1999) reported an alpha coefficient of 0.89. A sample item is, "I have sufficient authority to fulfill my job responsibilities."

Information Sharing: Information sharing was measured using a 10-item "information" scale developed by Vandenberg et al. (1999). These items assess the extent to which communication exists within the organization. Vandenberg et al. (1999) reported an alpha coefficient of 0.88 for this scale. A sample item is, "Management gives sufficient notice to employees prior to making changes in policies and procedures."

Reward and recognition: Reward and recognition was measured using a 7-item scale developed by Vandenberg et al. (1999) who reported an alpha coefficient of 0.86. A sample item is, "My performance evaluations within the past few years have been helpful to me in my professional development."

Teamworking: Team work was measured using a 6-item scale developed by Lawthom, Patterson, West and Maitlis (1992). This scale gauges the extent to which working in teams is supported and compensated within the organization. A sample item is, "This organization encourages people to work in teams."

Job Security: Perceived job security of employees was measured using three items adopted from Hellgren and Sverke (2003). These items were phrased: "I am worried about having to leave my job before I would like to," "There is a risk that I will have to leave my present job in the year to come," and 
"I feel uneasy about losing my job in the near future." They have been used to measure job insecurity, and were reverse-coded in this study to capture employees' perceptions of job security. Hellgren and Sverke (2003) reported a satisfactory internal consistency for this measure, with a coefficient alpha of 0.78 at time 1 and 0.79 at time 2 .

Selective Hiring: Selective hiring was assessed using a 5-item scale developed by Knight-Turvey and Neal (2003). These items are used to evaluate employee perceptions of an organisation's selection process based upon the suitability of newly hired staff members to complete assigned tasks. Knight-Turvey and Neal (2003) reported an alpha coefficient of 0.84. A sample item for this scale is, "This organisation strongly believes in the importance of hiring the right people for the job."

Performance Appraisal: Performance Appraisal was measured using a 3-items scale adopted from Chang (2005). The items for this scale were "Performance Appraisals are based on objective and quantifiable results," "Employees are allowed to formally communicate with supervisors regarding appraisal results," and "The Company has provided enough information regarding specific methods of the performance evaluation system."

\section{(2) Organizational Affective Commitment}

Affective commitment was assessed using Meyer, Allen and Smith's (1993) 6-item Affective Commitment Scale. This is a widely used and established instrument (see Rhoades, Eisenberger and Armeli 2001; Liden et al. 2003). Example items were "I would be very happy to spend the rest of my career with this organization"; "I really feel as if this organization's problems are my own." Coefficient alpha for the scale combining all items indicated sound reliability (alpha $=0.93)$.

\section{(3) Organizational Performance}

For organizational performance, a perceived measure was used because financial measures were not collected. While the use of perceptions of performance as opposed to measuring actual performance presents limitations through increased measurement error, it is not uncommon to use such measures. Dollinger and Golden (1992) have established that measures of perceived organizational performance correlate positively with objective measures of firm performance. For the purpose of this study, self-reported perceptions of performance are attained through the use of a multidimensional measure adapted from Gould-Williams (2003). This measure captures perceptions of value for money, service quality and service 
efficiency, with an alpha of .87. A sample item is, "This department provides excellent value for money."

\section{DATA ANALYSIS AND RESULTS}

All the variables used in this paper were normally distributed; Table 1 highlights the variables means, standard deviations and reliability alpha coefficients.

TABLE 1.

\begin{tabular}{llcccc}
\hline \multicolumn{1}{c}{ Variables } & Items & alpha & $\begin{array}{c}\text { Standard } \\
\text { Deviation }\end{array}$ & Mean \\
\hline 1 & Participative Decision Making & 7 & 0.936 & 0.91986 & 0.9795 \\
\hline 2 & Training and Development & 5 & 0.686 & 0.88584 & 1.3064 \\
\hline 3 & Information Sharing & 10 & 0.94 & 1.12567 & 1.482 \\
\hline 4 & Rewards and Recognition & 7 & 0.928 & 1.26702 & 1.5225 \\
\hline 5 & Team Working & 6 & 0.747 & 0.89794 & 1.3787 \\
\hline 6 & Selective Hiring & 5 & 0.698 & 0.88042 & 1.3523 \\
\hline 7 & Job Security & 3 & 0.891 & 1.22042 & 1.6626 \\
\hline 8 & Performance appraisal & 3 & 0.875 & 1.39057 & 1.7635 \\
\hline 9 & Organizational Commitment & 6 & 0.719 & 0.47328 & 2.2860 \\
\hline 10 & Organizational Performance & 5 & 0.731 & 1.01467 & 1.4275 \\
\hline
\end{tabular}

We conducted a series of multiple regression tests in order to test the relationship between HRM Practices and organizational performance with organizational commitment as mediating Factor:

The first equation regressed all HR practices against organizational commitment. The results showed that training and development $($ Beta $=.260$ ), selective hiring $($ Beta $=.251)$ and job security $($ Beta $=.175)$ were all significant at $\mathrm{p}<.001$, while Rewards and Recognition (Beta $=.189$ ) was significant at $\mathrm{p}<.001$. In the second equation, we regressed all HR Practices against organizational performance and the results showed that participative decision making $($ Beta $=.216)$, training and development $($ Beta $=.242)$, and selective hiring $($ Beta $=0.199)$ are all significant at the $\mathrm{p}<0.01$ level. We then regressed organizational commitment against organizational performance and the results showed that it was significant at the $\mathrm{p}<0.001$ level with Beta $=0.594$.

In order to test the mediating effect of organizational commitment it was regressed along with the HR Practices against organization performance and the results showed that participative decision making (Beta $=0.183$ ) was significant at $\mathrm{p}<0.001$, while training and development (Beta $=0.168)$, information 
sharing $($ Beta $=0.156)$, and selective hiring $($ Beta $=0.133)$ were all significant at the $\mathrm{p}<0.05$ level. The decrease in the significance of the independent variables indicates that organizational commitment can be considered as a mediating variable.

TABLE 2.

\begin{tabular}{|c|c|c|c|c|}
\hline & \multicolumn{4}{|c|}{ Results of Regression Analysis } \\
\hline & $\begin{array}{c}\text { Organizational } \\
\text { Commitment } \\
\text { Standardized } \\
\text { Beta }\end{array}$ & $\begin{array}{c}\text { Organizational } \\
\text { Performance } \\
\text { Standardized } \\
\text { Beta }\end{array}$ & $\begin{array}{c}\text { Organizational } \\
\text { Performance } \\
\text { Standardized } \\
\text { Beta }\end{array}$ & $\begin{array}{c}\text { Organizational } \\
\text { Performance } \\
\text { Standardized } \\
\text { Beta }\end{array}$ \\
\hline Participative Decision Making & 0.101 & $0.216^{* *}$ & & $0.183^{* * *}$ \\
\hline Training and Development & $0.260^{* * * *}$ & $0.242^{* *}$ & & $0.168^{*}$ \\
\hline Information Sharing & 0.032 & 0.137 & & $0.156^{*}$ \\
\hline Rewards and Recognition & $0.189^{* *}$ & -0.021 & & -0.075 \\
\hline Team Working & -0.020 & 0.054 & & 0.063 \\
\hline Selective Hiring & $0.251^{* * * *}$ & $0.199^{* *}$ & & $0.133^{*}$ \\
\hline Job Security & $0.175^{* * * *}$ & 0.049 & & 0.015 \\
\hline Performance appraisal & -0.026 & -0.064 & & -0.061 \\
\hline Organizational Commitment & & & $0.594^{* * * *}$ & $0.239^{* * *}$ \\
\hline $\mathrm{R}$ square & .582 & .480 & 0.353 & 0.505 \\
\hline $\mathrm{F}$ & $55.090^{* * *}$ & $36.744^{* * *}$ & $195.674^{* * *}$ & $35.626^{* * * *}$ \\
\hline
\end{tabular}

\section{DISCUSSION AND CONCLUSIONS}

As previously discussed, most research in this area was conducted in private entities and in Western countries. This study contributes to the HR-performance literature by exhibiting that organizational commitment can also have a mediating function between HR practices and organizational performance in the public sector and in a non-western setting.

As expected, the results illustrate that training and development can help in fostering employee commitment of public sector employees in the UAE, and that this in turn leads to an increase in performance of organizations in this region. This highlights the importance of investments in training and development in the public sector and in non-western countries-mainly as a tool that could help governmental organizations in developing their employees' commitment. Selective hiring also appears to assist entities in their efforts to promote commitment of their members with a resultant increase in their organizational performance. Our results also indicated that more autonomy in decision making directly influences organizational performance in the public sector in the UAE.

In conclusion, the results of this study shed more light on what could occur 
in the connection between HR practices and performance. Particularly the outcomes of the study, which was conducted in a context that was largely ignored by previous studies (the public sector within the UAE), offers further support to earlier conceptualizations on the mediating role of organizational commitment in between HRM and performance. It provides both researchers and practitioners with more knowledge on how human resource management could contribute to fostering more employee commitment and in turn, better organizational performance within a sector and a context (non-western) that requires substantially more research.

\section{LIMITATIONS AND FUTURE RESEARCH}

It is contended that the care taken in choosing the measures from previously validated and reliable scales led to the collection of valid data and that the analysis techniques employed were appropriate. Yet despite shedding further light on the linkages between HR practices and organizational performance, this study has its limitations. One limitation involves the study's use of self-report questionnaires to collect data on all measures. Data collected and used to test the hypotheses came from a single source-employees. Accordingly, the observed relationships may have been overstated as a result of employees' tendencies to respond in a consistent fashion to the items on the questionnaire.

Another possible methodological limitation of this study was the inability to assess causality in the relationships between study variables. The present research involved cross-sectional data and so no definitive statements can be made regarding the relationships between HR practices, organizational commitment, and organizational performance. Finally, our research sample was limited to two public entities within the UAE. This limited the generalization of our findings.

As discussed throughout this paper, one major area that has remained virtually unexplored involves the mechanism through which HRM practices affect organizational outcomes. While this study proposed that organizational commitment is one primary means by which such practices have their indirect effects, other variables that could potentially mediate the relationship between HR practices and organizational performance should be investigated by future research. Another focus by strategic human resource management scholars should be to research the above-mentioned links in a non-western context.

\section{REFERENCES}

Allen, N. J., and J. P. Meyer. 1996. Affective, continuance, and normative commitment to the organization: An examination of construct validity. Journal 


\section{of Vocational Behavior 49: 252-76.}

Allen, N. J., and J. P. Meyer. 1990. The measurement and antecedents of affective, continuance, and normative commitment to the organization. Journal of Occupational Psychology 63: 1-18.

Appelbaum, E., T. Bailey, and P. Berg. 2000. Manufacturing Advantage: Why High-Performance Systems Pay Off. Ithaca, NY: ILR Press.

Arthur, J. B. 1994. Effects of Human Resource Systems on Manufacturing Performance and Turnover. Academy of Management Journal 37(3): 670-87.

Bagraim, J. J. 2003. The nature and measurement of multiple commitment foci amongst South African knowledge workers. Management Dynamics: Contemporary Research 12(2): 13-23.

Barney, J. B. 1991. Firm Resources and Sustained Competitive Advantage. Journal of Management 17(1): 99-120.

Becker, B. E., and B. Gerhart. 1996. The impact of human resource management on organizational performance: progress and prospects. Academy of Management Journal 39(4): 779-801.

Becker, B. E., and M. Huselid. 1998. High performance work systems and firm performance: A synthesis of research and managerial implications. Research in Personnel and Human Resources Management 16: 53-101.

Boselie, P., G. Dietz, and C. Boon. 2005. Commonalities and contradictions in HRM and performance research. Human Resource Management Journal 15(3): 67-94.

Bowen, D. E., and C. Ostroff. 2004. Understanding HRM-Firm Performance Linkages: The role of the "Strength" of the HRM system. Academy of Management Review 29(2): 203-21.

Boxall, P., and J. Purcell. 2003. Strategy and Human Resource Management. Bristol: Palgrave.

Buitendach, J. H., and H. De Witte. 2005. Job insecurity, extrinsic and intrinsic job satisfaction and affective organisational commitment of maintenance workers in a parastatal. South African Journal of Business Management 36(2): 27-37.

Cascio, W. F. 1998. Managing human resources: Productivity, Quality of Work Life, Profits. $5^{\text {th }}$ Ed. USA: McGraw Hill.

Chang, E. 2005. Employees' overall perception of HRM effectiveness. Human Relations 58(4): 523-44.

Corsun, D. L., and C. A. Enz. 1999. Predicting psychological empowerment among service workers: The effect of support-based relationships. Human Relations 52(2): 205-24.

Delaney, J., and M. Huselid. 1996. The impact of human resource management practices on perceptions of organizational performance. Academy of Management Journal 39: 949-69.

Dillman, D. A. 2000. Mail and Internet Surveys: The Tailored Design Method. New York: Wiley. 
Farrell, M. A. 2003. The effect of downsizing on market orientation: The mediating roles of trust and commitment. Working paper, Faculty of Commerce Working Paper Series, Charles Stuart University.

Gaertner, K., and S. Nollen. 1989. Career experiences, perceptions of employment practices and psychological commitment to the organization. Human Relations 42(11): 975-91.

Gould-Williams, J. 2003. The importance of HR practices and workplace trust in achieving superior performance: A study of public-sector organizations. International Journal of Human Resource Management 14(1): 28-54.

Guest, D. E. 2002. Human resource management, corporate performance and employee wellbeing: Building the worker into HRM. The Journal of Industrial Relations 44(3): 335-58.

Hallier, J., and P. Lyon. 1996. Job Insecurity and Employee Commitment: Managers' Reactions to Threat and Outcomes of Redundancy Selection. British Journal of Management 7: 107-123.

Hellgren, J., and M. Sverke. 2003. Does job insecurity lead to impaired well-being or vice versa? Estimation of cross-lagged effects using latent variable modeling. Journal of Organizational Behavior 24(2): 215-36.

Huselid, M. 1995. The impact of human resource management practices on turnover, productivity, and corporate financial performance. Academy of Management Journal 38: 635-72.

Ichniowski, C., K. Shaw, and G. Prennushi. 1997. The effect of human resource management practices on productivity: A study of steel finishing lines. American Economic Review 87: 291-313.

Kinnie, N., J. Swart, B. Rayton, S. Hutchinson, and J. Purcell. 2004. HR Policy and Performance: An occupational analysis. Lisbon: 2004 Meeting of the HRM Study Group of the IIRA, $7^{\text {th }}$ IIRA European Regional Congress.

Kinnie, N., J. Swart, and J. Purcell. 2005. Influences of the choice of HR systems: The network organization perspective. International Journal of HRM 16(6): 1004-28.

Knight-Turvey, N. and A. Neal. 2003. High commitment human resource practices, affective organizational commitment, and employee level outcomes: The role of perceived organizational support. Australian Journal of Psychology 55(Supplement): 134.

Liden, R. C., S. J. Wayne, M. L. Kraimer, and R. T. Sparrowe. 2003. The dual commitments of contingents workers: An examination of contingents' commitment to the agency and the organization. Journal of Organizational Behavior 24: 609-25.

MacDuffie, J. 1995. Human resource bundles and manufacturing performance: Organizational logic and flexible production systems in the world auto industry. Industrial and Labor Relations Review 48(2): 197-221.

Macky, K., and P. Boxall. 2007. The relationship between 'high-performance 
work practices' and employee attitudes: An investigation of additive and interaction effects. The International Journal of Human Resource Management 18(4): 537-67.

Marchington, M., and I. Grugullis. 2000. 'Best practice' human resource management: Perfect opportunity or dangerous illusion? International Journal of Human Resource Management 11: 1104-24.

Mayer, R. C., and F. D. Schoorman. 1992. Predicting participation and production outcomes through a two-dimensional model of organizational commitment. Academy of Management Journal 35: 671-84.

Meyer, J. P., and N. J. Allen. 1997. Commitment in the workplace: Theory, research, and application. Thousand Oaks, CA: Sage.

Meyer, J. P., M. J. Allen, and C. A. Smith. 1993. Commitment to organizations and occupations: Extension and test of a three-component conceptualization. Journal of Applied Psychology 78(4): 538-51.

Meyer, J. P., and L. Herscovitch. 2001. Commitment in the workplace toward a general model. Human Resource Management Review 11: 299-326.

Mone, M. A. 1997. How we got along after the downsizing: Post-downsizing trust as a double-edged sword. Public Administration Quarterly 21(3): 309-36.

Mowday, R. T., L. W. Porter, and R. M. Steers. 1982. Employee-organization linkages: The psychology of commitment, absenteeism, and turnover. San Diego, CA: Academic Press.

Mowday, R. T., R. M. Steers, and L. W. Porter. 1979. The measurement of organizational commitment. Journal of Vocational Behavior 14: 224-47.

Nunnally, J. C. 1978. Psychometric Theory. $2^{\text {nd }}$ ed. New York: McGraw-Hill.

Ostroff, C., and D. E. Bowen. 2000. Moving HR to a higher level: Human resource practices and organizational effectiveness. In Multilevel theory, research, and methods in organizations, eds. K. J. Klein and S. W. Kozlowski, 211-66. San Francisco, CA: Jossey-Bass.

Peter, P. J. 1979. Reliability: A review of psychometric basics and recent marketing practices. Journal of Marketing Research 16(1): 6-17.

Porter, L. W., R. M. Steers, and R. T. Mowday. 1974. Organizational Commitment, Job Satisfaction, and Turnover among Psychiatric Technicians. Journal of Applied Psychology 59(5): 603-9.

Purcell, J. 1999. Best practice and best fit: Chimera or cul-de-sac? Human Resource Management Journal 9(3): 26-41.

Purcell, J., N. Kinnie, S. Hutchinson, B. Rayton, and J. Swart. 2003. Understanding the People and Performance Link: Unlocking the black box. London: Chartered Institute of Personnel and Development.

Purcell, J., N. Kinnie, J. Swart, B. Rayton, and S. Hutchinson. 2009. People Management and Performance. London: Routledge.

Randall, D. M., and M. P. O'Driscoll. 1997. Affective Versus Calculative Commitment: Human Resource Implications. The Journal of Social Psychology 137(5): 
606-17.

Rhoades, L., R. Eisenberger, and S. Armeli. 2001. Affective commitment to the organization: The contribution of perceived organizational support. Journal of Applied Psychology 86(5): 825-36.

Roth, P. L., and C. A. Bevier. 1998. Response rates in HRM/OB survey research: Norms and correlates, 1990-1994. Journal of Management 24: 97-117.

Snell, S. A., and J. W. Dean. 1992. Integrated manufacturing and human resources management: A human capital perspective. Academy of Management Journal 35: 467-504.

Vandenberg, R. J., H. A. Richardson, and L. J. Eastman. 1999. The impact of high involvement work processes on organizational effectiveness: A second-order latent variable approach. Group and Organization Management 24(3): 300-39.

Wright, P. M., and S. A. Snell. 1998. Toward a unifying framework for exploring fit and flexibility in strategic human resource management. Academy of Management Review 23(4): 756-72.

Youndt, M. A., S. A. Snell, J. W. Deanand D. P. Lepak. 1996. Human resource management, manufacturing strategy, and firm performance. Academy of Management Journal 39(4): 836-66. 